IMF Country Reports $\quad 22 / 041$

\title{
Dominica: Selected Issues
}




\section{INTERNATIONAL MONETARY FUND}

IMF Country Report No. 22/41

\section{DOMINICA}

\section{SELECTED ISSUES}

February 2022

This Selected Issues paper on Dominica was prepared by a staff team of the International Monetary Fund as background documentation for the periodic consultation with the member country. It is based on the information available at the time it was completed on January 18, 2022.

Copies of this report are available to the public from

International Monetary Fund • Publication Services

PO Box $92780 \bullet$ Washington, D.C. 20090

Telephone: (202) 623-7430 • Fax: (202) 623-7201

E-mail: publications@imf.org Web: http://www.imf.org

Price: $\$ 18.00$ per printed copy

\section{International Monetary Fund Washington, D.C.}

(c) 2022 International Monetary Fund

CInternational Monetary Fund. Not for Redistribution 


\section{INTERNATIONAL MONETARY FUND}

\section{DOMINICA}

\section{SELECTED ISSUES}

January 18,2022

\author{
Approved By \\ Western Hemisphere \\ Department
}

Prepared by Alejandro Guerson, Camila Perez Marulanda, Carolina Brozdowski, Salma Khalid (all WHD), Marina Mendes Tavares (RES), and Wei Guo (former SPR).

\section{CONTENTS}

\section{BUILDING RESILIENCE TO NATURAL DISASTERS: GROWTH AND INCOME} DISTRIBUTION IMPLICATIONS OF ALTERNATIVE GOVERNMENT FINANCING INSTRUMENTS

A. Introduction_______

B. General Model Description________ 4

C. Optimization Problems____ $\underline{7}$

D. Equilibrium_____

E. Calibration _

F. Results___

G. Benchmark _____ 14

H. Building Resilience _______ 15

I. Conclusion ______

References _____

\section{FIGURES}

1. The Impact of ND on the Benchmark Economy ___

2. Fiscal Instruments

\section{TABLES}

1. Model Structure ___

2. Parameters ___ 11

3. Moment Calibration Summary ____

4. Tax Changes in the Fiscal Policy Experiments ___ 14

5. Policy Instruments Rankings_____ 
MEASURING THE SHADOW ECONOMY IN DOMINICA

A. Background and Motivation

B. Measuring the Shadow Economy in Dominica using the MIMIC Model 


\section{BUILDING RESILIENCE TO NATURAL DISASTERS:}

\section{GROWTH AND INCOME DISTRIBUTION IMPLICATIONS OF ALTERNATIVE GOVERNMENT FINANCING INSTRUMENTS ${ }^{1}$}

Natural disasters disproportionally and recurrently affect small state economies like Dominica. This paper develops a multi-sector general equilibrium model and studies the macroeconomic and distributional implications of financing resilience-building using different fiscal instruments. The results indicate that investing in resilience capital is efficient despite its high economic cost, but the financial instrument used to mobilize revenue matters. When building resilience is financed using donors' support or by cutting unproductive government spending, the return of building resilience is higher than when it is financed via distortionary taxes.

\section{A. Introduction}

1. A multi-sector general equilibrium model is used to quantify the impact of building resilience in a SmDS economy using different fiscal instruments. The model captures critical macroeconomic and distributional features of small developing states (SDS). These include the high propensity of workers to migrate, particularly high-skilled, ${ }^{2}$ a large informal sector, and low output diversification. To capture distributional aspects, the model features different agent types:

(i) unskilled workers that work in the informal and agriculture sectors, (ii) skilled workers that can migrate or work in the high-skilled sector, (iii) government workers, (iv) entrepreneurs that own and invest private capital, and (v) a large farmer also own capital. It also includes a whole arrangement of fiscal instruments, including taxes on consumption, labor, and corporate profits, and features granular government expenditure allocations. In addition, it includes specific government spending allocations that affect income distribution and output, including transfers to households and government purchases of goods and services, public investment in infrastructure (resilient and nonresilient), and investment in human capital. Non-tax revenues are also included in the model and can be tailored to capture donor grants, citizenship by investment programs $(\mathrm{CBI})$, or natural resource revenue.

2. The model is calibrated to Dominica, and used to perform a series of counterfactual economic policy experiments to finance public investment resilient to natural disasters. Specifically, relatively more expensive resilient public capital is financed using three different tax

\footnotetext{
${ }^{1}$ Authored by Mendes-Tavares, Guo and Guerson.

2 For example, United Nations data indicates that about 80 percent of Caribbean nationals living in the diaspora are relatively "high skilled", defined as with complete a high school education or higher.
} 
instruments: value-added taxes, labor income tax, and corporate income tax. In addition, the paper analyzes financing it with donors' support and by cutting government spending.

\section{This paper contributes to a recent strand of the literature that has focused on the} macroeconomic impact of NDs and the benefits of investment in resilient infrastructure. The main feature in this literature is the distinction between capital that is resilient to disasters and capital that can be destroyed. Examples include Bevan and Adam (2014, 2016); Marto, Papageorgiou, and Kluyev (2017); Cantelmo, Melina, and Papageorgiou (2019); and Melina and Santoro (2021). However, much less is known about the economic cost and return of investment in physical or infrastructure resilience and how it interacts with the unique features of SDSs. This paper contributes to close this gap by studying the macroeconomic and distributional impact of raising revenue to finance resilient capital in an economy that considers critical features of SDSs. The model in this paper shares with this literature the critical distinction of capital types but incorporates a more granular specification of a prototypical SDS that are not included in these examples: an informal sector, labor migration, and remittances and its interactions with costly government investment in building resilience and the analysis of income distribution. These channels have been shown critical. For example, Boustan et al. (2017), using a database covering all NDs over 90 years in the United States, show that severe disasters increase outward migration rates permanently.

\section{The results indicate that investment in resilient capital is efficient despite its high} economic cost, but the financial instrument used to mobilize revenue matters. When building resilience is financed using donors' support, or by cutting unproductive government spending, the return of building resilience is higher than when it is financed via distortionary corporate income tax and labor income tax that reduce resource allocation efficiency. The corporate income tax is costlier because it reduces investment and the stock of private capital. The increase in the corporate tax rate lowers labor productivity and wages in the formal sectors. This effect is amplified in SDSs compared to other economies because corporate taxes generate out-migration of skilled workers, further reducing output. An increase in labor income tax has an intermediate negative impact on output. It also increases the out-migration of skilled workers, but the effect is smaller than that of corporate taxes.

5. Regarding the impact on the income distribution, using corporate taxes and labor income taxes reduce income inequality since these taxes are levied in the high-income workers. However, the use of these fiscal instruments result in a large economic cost in terms of output. Reducing government transfers lead to an increase income inequality since low-income workers typically benefit more from these transfers than other workers in the economy.

\section{B. General Model Description}

6. The model that captures key features of SDSs. Output is subject to NDs shocks that reduce total factor productivity transitorily and destroy a share of the capital stock. Workers can opt to migrate and send remittances back to the resident households. The model also allows the representation of a formal and informal labor markets, the later taking the form of an informal service sector which does not pay taxes. A formal service sector includes a tradable output, which 
captures another key feature of SDSs which often display large tourism and/or financial services sectors for export. Manufacturing goods are imported for consumption and, very importantly, also for investment purposes. This is a key model feature for small and undiversified states: output is dependent on imported capital, and thus external competitiveness is key to ensure not only the sustainability of consumption of imported goods, but also to facilitate investment for export.

7. The model specifies a small open economy. There are five types of households which maximize utility taking prices and government policies as given. Given specific assumptions about labor mobility and skill matching accrosss these sectors, this distinction enables to capture an important aspect about the impact of resilience building and its financing on income distribution.The households are assumed to work in specific sectors:

- Unskilled households - work for farmers or in the informal service sector.

- Skilled households - work for entrepreneurs in the formal sector or migrate

- Government Workers - work for the government or migrate.

- Farmers - hire labor and invest in the agriculture sector.

- Entrepreneurs - hire labor for the formal manufacturing and service sector and invest.

8. Every period three goods are produced: agriculture, manufacturing, and services. The subindex $t$ indicates time and it is omitted when unnecessary to simplify notation. Agriculture goods are produced using public capital $k^{g}$, private capital $k^{a}$, and labor $h^{*}$ in a cobb Douglas production function:

$$
y^{a}=z^{a}\left(k^{g}\right)^{\alpha^{g}}\left(k^{a}\right)^{\alpha^{*}}\left(h^{*}\right)^{1-\alpha^{*}-a^{g}}
$$

where $z^{a}$ is the productivity in the agriculture sector, $\alpha^{g}$ is the public capital share, and $\alpha^{*}$ is the private capital share. Manufacturing goods are produced using public capital $k^{g}$, private capital $k^{a}$, and labor $h^{e, m}$ in a cobb Douglas production function:

$$
y^{m}=z^{m}\left(k^{g}\right)^{\alpha^{g}}(k)^{\alpha^{m}}\left(h^{e, m}\right)^{1-\alpha^{m}-a^{g}}
$$

where $z^{m}$ is the productivity in the manufacturing sector, $\alpha^{g}$ is the public capital share, and $\alpha^{m}$ is the private capital share. Services good can be produced in the formal or informal sectors and use labor as the only input with decreasing returns:

$$
y^{s}=z^{s} \theta(h)^{\alpha}
$$

where $z^{s}$ is the productivity in the services sector, $\alpha$ is the labor share, and $\theta$ is a parameter that captures the disruption in the production of services goods caused by a ND shock. Private capital in the economy depreciates at rate $\delta$ and evolves following a capital law of motion:

$$
k_{+}=(1-\delta) k+x
$$


where $x$ is private investment. Public capital includes resilient $k_{r}$ and non-resilient public capital $k_{n}$. NDs destroy a share of $\delta_{d}$ of non-resilient capital with a probability $p_{d}$ in each period. The law of motion of the public capital stock is therefore given by

$$
\begin{gathered}
k_{r,+}=\left(1-\delta_{g}\right) k_{r}+I_{r}, \\
k_{n,+}=\left(1-\delta_{g}-p_{d} \delta_{d}\right) k_{n}+I_{n} .
\end{gathered}
$$

where $I_{r}$ is the government investment in resilient capital and $I_{n}$ is the government investment in non-resilient capital. Resilient and non-resilient capital depreciates at rate $\delta_{g}$. Building non-resilient capital is cheaper than building resilient capital and $p_{r, n}$ is the relative unit price from resilient capital to non-resilient capital.

\section{Households consumed and supply labor, including the decision to migrate and send} remittnaces to the household. They consume agriculture goods $c^{a}$, manufacturing goods $c^{m}$, and services $c^{s}$. Skilled and government workers households also decide how much labor to supply domestically $h$ and how much labor to supply to a foreign market (out-migration) $1-h$. Unskilled households decide how much labor to supply domestically to the agriculture sector $h^{u}$ and how much labor supply to the informal sector $1-h^{u}$. Farmers and entrepreneurs in addition decide how much capital invest in their own business $x$.

10. The government sector includes a granular menu of fiscal policy instruments. The government collects tax revenue (value-added taxes on agriculture goods $\tau^{a}$, value-added taxes on manufacturing goods $\tau^{m}$, value-added taxes on service goods $\tau^{s}$, corporate taxes $\tau^{k}$, and personal income tax $\tau^{w}$ ) and nontax-revenue (mainly citizenship by investment program and donor grants). ${ }^{3}$ Government revenue is used to fund government expenditures including public sector wages $w^{g}$, public investment in resilience $I_{r}$, and non-resilience capital $I_{n r}$, and transfers to government workers $T^{g}$, transfers to skilled workers $T^{s}$, transfers to unskilled workers $T^{u}$, and to service public debt $D$.

\footnotetext{
${ }^{3} \mathrm{CBI}$ importance has increased significantly in recent years in several SDS, especially in the Caribbean. SDS/LICS typically also receive significant foreign donor grants and aid relative to their size.
} 


\begin{tabular}{|c|c|c|c|c|}
\hline \multicolumn{5}{|c|}{ Table 1. Dominica: Model Structure } \\
\hline Good & Producer & Input & Use & Commerce \\
\hline Agriculture & Farmers & $\begin{array}{l}\text { Unskilled Labor } \\
\text { and Capital }\end{array}$ & Consumption & Tradable \\
\hline Manufacturing & Entrepreneurs & $\begin{array}{l}\text { Skilled Labor and } \\
\text { Capital }\end{array}$ & $\begin{array}{l}\text { Consumption } \\
\text { and } \\
\text { Investment }\end{array}$ & Tradable \\
\hline Services & $\begin{array}{l}\text { Unskilled Labor } \\
\text { and } \\
\text { Entrepreneur }\end{array}$ & Labor & Consumption & $\begin{array}{l}\text { Non- } \\
\text { Tradable }\end{array}$ \\
\hline Public Goods & Government & $\begin{array}{l}\text { Public Workers } \\
\text { and } \\
\text { Manufacturing } \\
\text { Goods }\end{array}$ & $\begin{array}{l}\text { Infrastructure, } \\
\text { Education, and } \\
\text { Social } \\
\text { Transfers }\end{array}$ & $\begin{array}{l}\text { Non- } \\
\text { Tradable }\end{array}$ \\
\hline
\end{tabular}

\section{Optimization Problems}

11. Workers maximize expected lifetime utility by solving an intertemporal optimization problem. Each period they choose consumption of each good, and labor supplied in the different markets available to each. Entrepreneurs and farmers choose investment and labor demand.

Government Worker. Government workers are a share $\mu^{g}$ of the population. They choose labor supply to the government $h_{t}^{g}$ at a set public wage $w^{g}$ or to migrate and work in foreign countries $1-h_{t}^{g}$, earning the foreign wage $w^{u s}$. They solve the following optimization problem:

$$
\max _{\left\{c_{t}^{g, a}, c_{t}^{g, m}, c_{t}^{g, s}, h_{t}^{g}\right\}} E\left(\sum_{t=0}^{\infty} \beta^{t}\left(\log \left(c_{t}^{g, a}\right)+\gamma \log \left(c_{t}^{g, s}\right)+\psi \log \left(c_{t}^{g, m}\right)\right)\right)
$$

s.t.

$$
\begin{gathered}
\left(1+\tau^{a}\right) p^{a} c_{t}^{g, a}+\left(1+\tau^{m}\right) c_{t}^{g, m}+p_{t}^{s}\left(1+\tau^{s}\right) c_{t}^{g, s} \\
=\left(1-\tau^{w}\right) w_{t}^{g} h_{t}^{g}+\left(1-h_{t}^{g}\right)^{\alpha} w^{u s}+T_{t}^{g} \\
h_{t}^{g} \in[0,1]
\end{gathered}
$$

Skilled workers. Skilled workers are set at a population share $\mu^{s}$. They choose labor suply in the domestic economy $h_{t}^{s}$ and earn skiled labor wage $w$ in the formal sector (manufacturing) or to migrate and supply labor in foreign markets $1-h_{t}^{s}$ and earn a foreign wage $w^{u s}$, in which case they send remittances to the household $\left(1-h_{t}^{s}\right)^{\alpha} w^{u s}$. They solve:

$$
\max _{\left\{c_{t}^{s, a}, c_{t}^{s, m}, c_{t}^{s, s}, h_{t}^{s}\right\}} E\left(\sum_{t=0}^{\infty} \beta^{t}\left(\log \left(c_{t}^{s, a}\right)+\gamma \log \left(c_{t}^{s, s}\right)+\psi \log \left(c_{t}^{s, m}\right)\right)\right)
$$

s.t.

$$
\left(1+\tau^{a}\right) p^{a} c_{t}^{s, a}+\left(1+\tau^{m}\right) c_{t}^{s, m}+p_{t}^{s}\left(1+\tau^{s}\right) c_{t}^{s, s}=
$$




$$
\begin{gathered}
\left(1-\tau^{w}\right) w_{t}^{s} h_{t}^{s}+\left(1-h_{t}^{s}\right)^{\alpha} w^{u s}+T_{t}^{s} \\
h_{t}^{s} \in[0,1]
\end{gathered}
$$

Unskilled workers. They are ashare $\mu^{u}$ of the population. They choose how labor supply in the agriculture sector $h_{t}^{u}$ and earn an agriculture wage $w_{t}^{f}$ or to work in the informal services sector and supply labor $1-h_{t}^{u}$ to that sector and earn revenue $y^{s} . T_{t}^{s}$ is the government transfer to the unskilled service sector worker household. The optimization problem of an unskilled worker is given by

$$
\max _{\left\{c_{t}^{u, a}, c_{t}^{u, m}, c_{t}^{u, s}, h_{t}^{u}\right\}} E\left(\sum_{t=0}^{\infty} \beta^{t}\left(\log \left(c_{t}^{u, a}\right)+\gamma \log \left(c_{t}^{u, s}\right)+\psi \log \left(c_{t}^{u, m}\right)\right)\right)
$$

s.t.

$$
\begin{gathered}
\left(1+\tau^{a}\right) p^{a} c_{t}^{u, a}+\left(1+\tau^{m}\right) c_{t}^{u, m}+p_{t}^{s}\left(1+\tau^{s}\right) c_{t}^{u, s}=w_{t}^{f} h_{t}^{u}+y_{t}^{s}+T_{t}^{u} \\
y_{t}^{s}=p_{t}^{s} z^{s} \theta\left(1-h_{t}^{u}\right)^{\alpha} \\
h_{t}^{u} \in[0,1]
\end{gathered}
$$

Entrepreneurs. There is a share $\mu^{e}$ of entrepreneurs in the population. Entrepreneurs own capital $k$ and they decide investment $x_{t}^{e}$. They also demand labor for the formal tradeable sector ("manufacturing") $h_{t}^{e, m}$ and for the formal non-traded ("services") sector $h_{t}^{e, s}$. The entrepreneur maximization problem is given by

$$
\max _{\left\{c_{t}^{e, a}, c_{t}^{e, m}, c_{t}^{e, s}, h_{t}^{e, m}, h_{t}^{e, s}, k_{t}\right\}} E\left(\sum_{t=0}^{\infty} \beta^{t}\left(\log \left(c_{t}^{e, a}\right)+\gamma \log \left(c_{t}^{e, s}\right)+\psi \log \left(c_{t}^{e, m}\right)\right)\right)
$$

s.t.

$$
\begin{gathered}
\left(1+\tau^{a}\right) p^{a} c_{t}^{e, a}+\left(1+\tau^{m}\right) c_{t}^{e, m}+p_{t}^{S}\left(1+\tau^{s}\right) c_{t}^{e, s}+x_{t}^{e}=\left(1-\tau^{k}\right) \pi_{t}^{*}+\left(1-\tau^{k}\right) \pi_{t}^{S}+T_{t}^{e} \\
\pi_{t}^{*}=y_{t}^{m}-w_{t}^{s} h_{t}^{e, m}-\epsilon \frac{\left(k_{t}-k_{t-1}\right)^{(1-\sigma)}}{1-\sigma} \\
\pi_{t}^{S}=p_{t}^{S} z^{e, s} \theta\left(h_{t}^{e, s}\right)^{\alpha}-w_{t}^{S} h_{t}^{e, s} \\
k_{t}=(1-\delta) k_{t-1}+x_{t}^{e} \\
h^{e} \geq 0
\end{gathered}
$$

$\tau^{k}$ is the tax rate on profits, or the corporate income tax. $T_{t}^{e}$ is the government transfer to the entrepreneur household. Private capital follows a law of motion and depreciates at rate $\delta$.

Entrepreneurs also face adjustment costs to the level of capital investment $\epsilon \frac{\left(k_{t}-k_{t-1}\right)^{(1-\sigma)}}{1-\sigma}$, where $\epsilon$ is a scaling elasticity and $\sigma$ governs the increase in adjustment cost according to the speed of investment. 
Farmers. They have a share $\mu^{a}$ in total population. Farmers own capital $k_{t}^{a}$ and decide investment $x_{t}^{a}$, and labor demand for agriculture $h_{t}^{f}$. Agricultural goods are exported, allowing the economy to earn foreign exchange needed to import manufacturing inputs. Farmers solve the optimization problem

$$
\max _{\left\{c_{t}^{e, a}, c_{t}^{e, m}, c_{t}^{e, s}, h_{t}^{f},,_{t}^{a}\right\}} E\left(\sum_{t=0}^{\infty} \beta^{t}\left(\log \left(c_{t}^{f, a}\right)+\gamma \log \left(c_{t}^{f, s}\right)+\psi \log \left(c_{t}^{f, m}\right)\right)\right)
$$

s.t.

$$
\begin{aligned}
& \left(1+\tau^{a}\right) p^{a} c_{t}^{f, a}+\left(1+\tau^{m}\right) c_{t}^{f, m}+p_{t}^{s}\left(1+\tau^{s}\right) c_{t}^{f, s}+x_{t}^{a}=\left(1-\tau^{k}\right) \pi_{t}^{a}+T_{t}^{f} \\
& \pi_{t}^{a}=p^{a} y_{t}^{a}-w_{t}^{f} h_{t}^{f}-\epsilon \frac{\left(k_{t}^{a}-k_{t-1}^{a}\right)^{(1-\sigma)}}{1-\sigma} \\
& k_{t}^{a}=(1-\delta) k_{t-1}^{a}+x_{t}^{a} \\
& h_{t}^{f} \geq 0
\end{aligned}
$$

$T_{t}^{f}$ is the government transfer to the farmer household. Private capital follows a law of motion and depreciates at rate $\delta$. Farmers also face adjustment costs $\epsilon \frac{\left(k_{t}^{a}-k_{t-1}^{a}\right)^{(1-\sigma)}}{1-\sigma}$.

Government. The government collects tax and nontax revenue, and spends the proceeds in transfers, public employment, public investment, human capital (health and education), and debt service. The model includes taxes on consumption, labor income, and corporate income. In addition, the government collects nontax revenue $N R$ and receives foreign grants $G R$. Public investment can be resilient to NDs, $I_{r, t}$, or non-resilient $I_{n, t} . \lambda$ is defined as the relative share of investment in resilient to non-resilient capital, $I_{n, t}=\lambda I_{r, t}$. Resilient investment is not destroyed or damaged by NDs. It yields the same output as non-resilient investment, but it comes at an extra cost of $p_{r, n}>1$. This implies it takes more units of investment to accumulate the same amount of resilient capital stock compared with non-resilient type. Consumption tax revenue is defined as

$R_{t}^{c}=\tau_{t}^{a} p^{a} C_{t}^{a}+\tau^{m} C_{t}^{m}+\tau^{s} p^{s} C_{t}^{s}$

Revenue from the corporate tax is defined as

$$
R_{t}^{k}=\tau_{t}^{k}\left(\mu^{f} \pi_{t}^{a}+\mu^{e} \pi_{t}^{*}+\mu^{e} \pi_{t}^{S}\right)
$$

and tax revenue from labor income

$$
R_{t}^{w}=\tau_{t}^{w}\left(\mu^{s} w h_{t}^{s}+\mu^{g} w h_{t}^{g}\right)
$$

Total government transfers are the weighted sum of the transfers to all agents in the economy:

$$
T_{t}=\mu^{u} T_{t}^{u}+\mu^{s} T_{t}^{s}+\mu^{f} T_{t}^{f}+\mu^{e} T_{t}^{e}+\mu^{g} T_{t}^{g}
$$


12. The government is the only participant in the economy that can borrow externally at the risk-free international interest rate $r^{*}$. The dynamic budget constraint is given by

$0=R_{t}^{c}+R_{t}^{k}+R_{t}^{w}+N R_{t}+G R_{t}-p_{r, n} I_{r, t}-I_{n, t}-I_{t}^{h}-T_{t}-C E_{t}-\left(1+r^{*}\right) D_{t}+D_{t+1} \cdot(6)$

\section{Equilibrium}

13. A recursive competitive equilibrium is comprised by decision rules $\left\{c_{t}^{i a}, c_{t}^{i m}, c_{t}^{i s}, h_{t}^{i}\right\}_{t=0}^{\infty}$ for each type of household $i \in\{u, g, s, e, a\}$ and $k_{t}^{j}$ for $j \in\{m, a\}$, for entrepreneurs and farmers, and factor prices $\left\{p_{t}^{s}\right\}_{t=0}^{\infty}$ and wages $\left\{w_{t}^{f}, w_{t}^{s}\right\}_{t=0}^{\infty}$ such that given prices of $\left\{p^{m}=1, w^{g}, w^{u s}\right\}$ and government policies $\left\{\tau_{t}^{a}, \tau_{t}^{m}, \tau_{t}^{s}, \tau_{t}^{k}, \tau_{t}^{w}, G r_{t}, T_{t}, I_{t}^{h}, I_{r, t}, I_{n, t}\right\}_{t=0^{\prime}}^{\infty}$ the decision rules together with prices satisfy the following conditions:

- Households solve their optimization problem for the government workers (1), unskilled workers (2), skilled workers (3), entrepreneurs (4) and big farmers respectively (5).

- Labor market clearing of skilled workers is satisfied: $\mu^{s} h^{s}=\mu^{e} *\left(h^{e, m}+h^{e, s}\right)$

- Labor market clearing of unskilled workers is satisfied: $\mu^{u} h^{u}=\mu^{f} h^{*}$

- Services good market clears:

$$
\mu^{u} c^{u, s}+\mu^{r} c^{r, s}+\mu^{e} c^{e, s}+\mu^{f} c^{f, s}=\mu^{u} z^{s}\left(1-h^{u}\right)^{\alpha}+\mu^{e}\left(p_{s} z^{e, s}\left(h^{e, s}\right)^{\alpha}\right)
$$

- Government budget (6) constraint is satisfied.

\section{E. Calibration}

\section{The model is used to analyze different fiscal instruments to finance the buidling of} resilience public capital. The model is calibrated to match the quantitative parameters of the Dominica economy, a SDS island in the Caribbean. The calibration matches sector sizes, use of labor and capital and inter-sector linkages as well as the distribution of income: ${ }^{4}$

Preferences. Households' preferences over manufacturing goods $(\psi)$, services $(\gamma)$ and agriculture goods are calibrated so that consumption shares in the model match those in the consumer price index (CPI) basket, where we consider the manufacturing sector to map close to the tradable sector

\footnotetext{
${ }^{4}$ Income distribution in Dominica is proxied with data from the social security administration, which provides employment and average salary by economic sector.
} 
Labor Force. Labor market parameters, including the distribution of labor across different types of households in the model, are based on data from the Dominica Social Security Administration. Specifically, the sectoral data on employment is allocated as follows: (i) government workers $\left(\mu^{g}\right)$ : public sector; (ii) skilled workers $\left(\mu^{S}\right)$ : manufacturing, utilities, trade, tourism and financial sector; (iii) unskilled workers $\left(\mu^{u}\right)$ : agriculture, fishing, mining and construction. The remaining sectors are distributed between entrepreneurs $\left(\mu^{e}\right)$ and farmers $\left(\mu^{f}\right)$. Moreover, emigrants - whose number is close to the size of Dominica's domestic population — are allocated to skilled workers and government workers. Finally, emigration elasticity $(\alpha)$ has been estimated based on the share of the Dominican population working abroad, while wages in the United States $\left(w^{u s}\right)$ are calibrated so that remittance flows in the model match the actual data (Table 2).

Economic Sectors. Productivity in the agricultural $\left(z^{a}\right)$, formal $\left(z^{e, s}\right)$ and informal services $\left(z^{s}\right)$ sectors is calibrated so that the sizes of the sectors in the model match National Accounts data. For example, agriculture and services (both informal and formal) are estimated to account for 17 and 51 percent of GDP, respectively. The elasticity to private capital $\left(\alpha^{m}, \alpha^{*}\right)$ and to public capital $\left(\alpha^{g}\right)$ are set as estimated in Valentinyi and Herrendorf (2008) (Table 3). Private $(\delta$ ) and public physical capital depreciation $\left(\delta_{g}\right)$ are calculated as the weighted average of depreciation rates by type of capital from Inklaar and Timmer (2013).

\begin{tabular}{|c|c|c|}
\hline \multicolumn{3}{|c|}{ Table 2. Dominica: Parameters } \\
\hline Parameter & & Values \\
\hline \multicolumn{3}{|c|}{ Demographics } \\
\hline$\mu^{g}$ & share of government workers & 0.349 \\
\hline$\mu^{s}$ & share of skilled workers & 0.444 \\
\hline$\mu^{u}$ & share of unskilled workers & 0.105 \\
\hline$\mu^{e}$ & share of entrepreneur & 0.049 \\
\hline$\mu^{f}$ & share of big farmers & 0.053 \\
\hline \multicolumn{3}{|c|}{ Fiscal Policy } \\
\hline$r^{*}$ & interest rate in government debt & 0.029 \\
\hline \multicolumn{3}{|c|}{ Other Parameters } \\
\hline $\mathrm{B}$ & discount factor & 0.96 \\
\hline $\bar{c}$ & lower bound of agricultural consumption & 0.20 \\
\hline$\alpha$ & emigration elasticity & 0.5 \\
\hline$\alpha^{m}$ & tradable elasticity to private capital & 0.24 \\
\hline$\alpha^{*}$ & agriculture elasticity to private capital & 0.40 \\
\hline$\alpha^{g}$ & elasticity to public capital & 0.14 \\
\hline$\delta$ & private capital depreciation & 0.14 \\
\hline$\delta_{g}$ & public capital depreciation & 0.109 \\
\hline
\end{tabular}

Fiscal Policy. Government revenue and expenditure parameters are set to fit central government data. Specifically, tax rates on consumption $\left(\tau^{a}, \tau^{m}, \tau^{s}\right)$, personal income $\left(\tau^{w}\right)$ and corporate profits $\left(\tau^{k}\right)$ are calibrated to yield revenue close to effective revenue collections. Non-tax revenues (NR) are calibrated to match flows mainly from the Citizenship-by-Investment (CBI) program. Similarly, grants 
$(G r)$ are aligned with actual current and capital grants. Transfers to households $\left(T^{u}, T^{s}, T^{f}, T^{e}, T^{g}\right)$ are calibrated to match spending on transfers mapped to the workers in each sector with social security data, while public sector wages $\left(w^{g}\right)$ are calibrated so that public sector wage bill is in line with the compensation of employees in the data. The interest rate on government debt $\left(r^{*}\right)$ is calculated as the implied interest rate on outstanding debt (see Table 2).

Natural Disasters. When there is a ND, there are both temporary efficiency loss in capital and labor productivity $\theta$ and additional recovery loss in depreciation rate $\delta_{d}$. It is assumed that this shock reduces the stock of non-resilient public capital by 40 percent, impacting the manufacturing and agriculture sectors. The ND shock also impacts the productivity of the formal and informal services sector transitorily, for one period (one year). This represents loss of investment productivity due to need for rehabilitation observed after NDs, typically rendering infrastructure temporarily unproductive or unusable even if not destroyed. The size of the productivity decline is calibrated to obtain a 5 percent drop in GDP, which captures a relatively large size ND, about one standar deviation of destruction as a share of GDP by a hurricane, based on the ND Annual Loss curve for Dominica.

\begin{tabular}{|c|c|c|c|}
\hline Parameter & & Madal & \\
\hline & \multicolumn{3}{|c|}{ Preferences (percent) } \\
\hline$\psi$ & Share of tradables in total consumption & 35.9 & 35.9 \\
\hline \multirow[t]{2}{*}{$\gamma$} & Share of services in total consumption & 42.2 & 42.2 \\
\hline & \multicolumn{3}{|c|}{ Economic Indicators (percent of GDP) } \\
\hline$z^{a}$ & Agricultural output & 16.8 & 16.8 \\
\hline$z^{e, s}$ & Services output & 50.9 & 50.9 \\
\hline$z^{S}$ & Informal sector output & 3.7 & 3.7 \\
\hline \multirow[t]{2}{*}{$w^{u s}$} & Remittances & 10.0 & 10.0 \\
\hline & \multicolumn{3}{|c|}{ Fiscal Policy (percent of GDP) } \\
\hline$\tau^{a}, \tau^{m}, \tau^{s}$ & Revenue from consumption tax & 13.5 & 13.5 \\
\hline$\tau^{w}$ & Revenue from personal income tax & 4.5 & 4.5 \\
\hline$\tau^{k}$ & Revenue from corporate taxes & 4.0 & 4.0 \\
\hline$G r$ & Grants & 5.0 & 5.0 \\
\hline$N R$ & Non-tax revenues & 10.0 & 10.0 \\
\hline$w^{g}$ & Public sector wage bill & 11 & 11 \\
\hline$K_{0}^{g}$ & $\begin{array}{l}\text { Public Capital investment over GDP in } \\
\text { steady state }\end{array}$ & 12 & 12 \\
\hline$T^{u}, T^{s}, T^{f}, T^{e}, T^{g}$ & Transfers to households & 5.5 & 5.5 \\
\hline
\end{tabular}




\section{F. Results}

\section{The model is used to simulate a policy shock followed by a ND shock:}

- It is assumed the economy starts from a non-resilient state, in the sense that, if hit by a NDs, a share of its infrastructure is destroyed.

- At time zero, the government starts investing in resilient infrastructure. Because this policy shift implies a fiscal cost, it is assumed the government also uses one of its policy instruments to finance the increase in the investment spending.

- $\quad$ Five alternative financing instruments are studied to finance the additional government expense of investment in resilient capital: consumption tax, corporate tax (profits), payroll tax, reduction in public sector wage, and an increase in donor financing. The use of each fiscal policy instrument is calculated to collect 1 percent of GDP in the steady state. The additional government resources are used to finance investment in resilient public capital. ${ }^{5}$

- In period ten, a ND shock occurs. It is assumed that this shock reduces the stock of nonresilient public capital by 40 percent, impacting the manufacturing and agriculture sectors. The ND shock also impacts the productivity of the formal and informal services sector transitorily, for one period (one year).

- After the shock, the economy converges to a new steady state with a higher level of resilient public capital.

\section{The experiment is designed to showcase the channels though which NDs affect the} economy. The objective is to shed light on the choice of adaptation financing instruments, the relative efficiency and income distribution implications of each option. It also illustrates the role the international donor community can play by providing grants in supporting ex-ante investment in adaptation and resiliency-as opposed to disbursing ex-post grants for recovery after major NDs had occurred. Given that resilient infrastructure is more costly, the choice of policy instrument for financing has implications on economic performance and income distribution. Specifically, the instruments have a different endogenous reaction of all participants in the economy and a distinctive distortionary impact affecting resource allocation efficiency. The results indicate that targeting 1 percent of GDP in revenue with the value-added (consumption) tax requires a relatively small increase in the tax rate compared with the labor income tax and corporate tax. This is because it is relatively more efficient, and also because of the broader tax base (Table 4).

\footnotetext{
${ }^{5}$ Notice that debt financing has not been considered. This is because debt financing would require a fiscal adjustment to service the increase in debt, which would revert the analysis back to the consideration of which fiscal instrument to use to that effect. The experiment is designed to aess the efficiency and distributional impact of alternative government financing options, as opposed to inter-temporal financing trade-offs.
} 


\begin{tabular}{|lcc|}
\hline \multicolumn{2}{|c|}{ Table 4. Dominica: Tax Changes in the Fiscal Policy Experiments } \\
& Benchmark Values & Policy Change (\%) \\
VAT & 0.12 & $5.2 \%$ \\
PIT & 0.06 & $15.0 \%$ \\
CIT & 0.10 & $17.2 \%$ \\
Public Sector Wages & 0.27 & $2.1 \%$ \\
Transfers & 0.02 & $-9.0 \%$ \\
\hline
\end{tabular}

\section{G. Benchmark}

17. Impulse-response analysis illustrates the working of the model for the experiment under consideration for the benchmark economy with no investment in resilience capital. In this case, output declines by 16 percent with non-resilient public capital. As expected, capital intensive sectors experienced a large decline after the ND shock than sectors that are less intensive in capital. The manufacturing sector tops the ranking, followed by agriculture. The services sector output, both formal and informal, decline by relatively less. The ND shock also stimulates outmigration because skilled workers experience a wage loss due to the shock in the manufacturing sector (Figure 1).

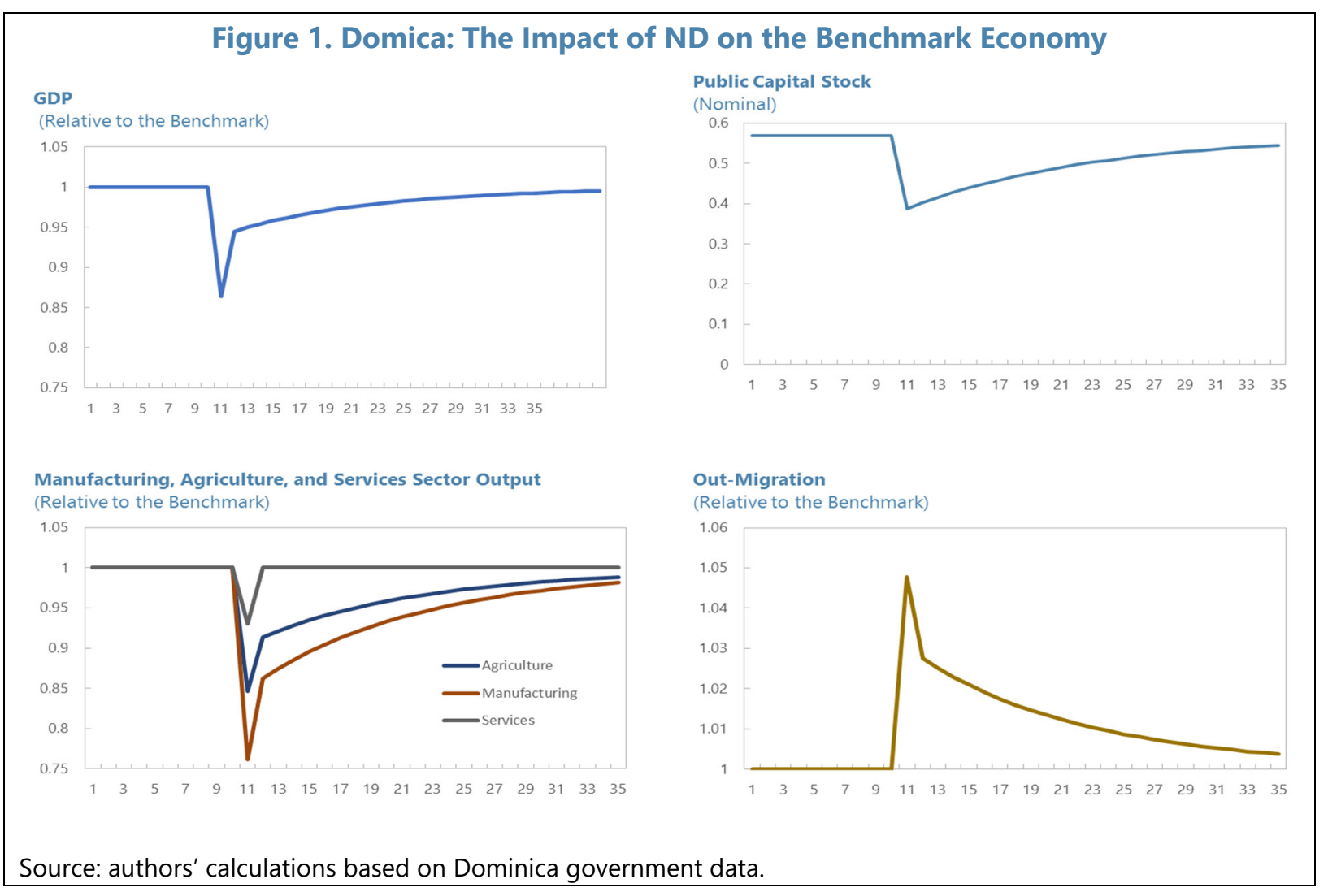


18. NDs shocks increases income inequality by affecting sectors with relatively lower wages disproportionally. Unskilled workers, which in the model capture the relatively poorer households, suffer more from the ND than skilled workers because the latter can migrate, seeking employment abroad and therefore containing the wage decline in their sector by reducing the domestic labor supply, and send remittances for consumption that support their household welfare. This means that that workers out-migration operates as de-facto insurance against NDs, both for workers that stay in the domestic economy. Government workers' wage is assumed to remain unchanged, an empirical regularity. ${ }^{6}$ Migration dynamics also help mitigate the drop of income in the informal sector. The migration of formal sector workers reduces their participation in the formal service sector, which results in an employment substitution that increases the relative demand in the informal service sector that employs unskilled workers. Farmers and entrepreneurs are negatively affected by the ND shock because of the asset loss as per the destruction of the stock of capital, and a related loss of income.

\section{H. Building Resilience}

\section{Resilient investment reduces the impact of the ND shock on output by 2 to}

2.5 percentage points depending on the financing instrument. Raising revenue with the valueadded tax is most efficient (as measured by the impact on output) because it is relatively less distortionary, stimulating saving and investment. On the other hand, the corporate income tax is costlier because it reduces investment and the stock of private capital, lowering labor productivity and wages in the formal sectors. This impact is further amplified by the out-migration of skilled workers. An increase in the labor income tax has an intermediate negative impact on output: it also increases out-migration of skilled workers. A reduction in government wage expenditure is less distortionary under the model assumptions (government workers have zero marginal contribution to output). Unsurprisingly, an increase in donor's finance is the most beneficial instrument because it is a "gift" and causes no tax distortions. When building resilience is financed by cutting unproductive government spending, the return of building resilience is higher than when it is financed via distortionary corporate income tax and labor income tax that reduce resource allocation efficiency.

\section{The fiscal instrument used to finance the cost of resilient investment affects income} distribution. As expected, resilience financing with an increase in corporate taxes reduces income inequality because it is levied on the relatively higher income households, the skilled workers in the formal sectors and entrepreneurs. The labor income tax also reduces income inequality because it affects relatively high-income government employees and skilled workers, while workers in the informal sector are not taxed. Interestingly, the value-added tax results in a small decline in income inequality. This is because of a combination of reasons that are specific to the SDS assumptions in this model. On first impression, unskilled workers with low wage would be more affected by an increase in the consumption tax, including because they cannot migrate after a ND and also because they cannot save. However, unskilled workers increase working hours in the informal service sector

\footnotetext{
${ }^{6}$ Notice that the assumption that public sector workers can migrate imposes a floor on government wages, implying that the financing of resilience investment with reduction in the wage bill is met with a decline in public sector employment and out-migration.
} 
as formal service sector is affected by out-migration. This helps maintain their wage earnings, which is further aid by the fact they are not paying taxes as informal workers.

\section{A reduction of government workers' wage expense reduces income inequality because government wages are higher than that of most sectors in the Dominica economy. A cut in} government transfers increases income inequality, even if the transfer is cut is applied proportionally to all household types in the model. Relatively wealthy households have small proportional reduction in total household income, while low income households face a large decline since the government transfers is a larger share of their income.

\section{The impact on the welfare of the different households can be illustrated by the} predicted response of consumption (text charts). The alternative financing instruments have different impact on unskilled vs. skilled worker households:

- Unskilled workers. The hand-to-mouth assumption and inability to migrate of unskilled workers results in a decline in consumption when the ND strikes, unlike in the skilled worker household due to out-migration and remittance income. However, resilient investment reduces the concurrent decline in consumption when the ND hits the economy. The corporate income tax financing affects consumption the least compared with the benchmark of no resilient investment, as expected. Labor tax financing also has a relatively small effect on unskilled workers wage, mainly because these workers are informal and pay no labor tax. The consumption or VAT tax financing reduces the consumption of unskilled workers more significantly because these workers, being hand-to-mouth, have a high propensity to consume. Financing with a decline in transfers has the highest impact on unskilled workers' consumption. This is because, unlike the VAT increase, there is no consumption substitution nor labor reallocation across sectors that can help unskilled households avoid or mitigate the impact.

- Skilled workers. The possibility of migration allows skilled workers to smooth income and consumption when the economy is hit by a ND, resulting in no concurrent welfare loss and therefore resulting in no resilience investment benefit. This extreme result is due to the simplifying assumption that there are no delays nor cost of migration. However, the experience of the NDs in Dominica in 2015 and 2017 shows that labor migration, although not immediate, occurred soon after the hurricane shock, within the six months that followed the ND shock. The ranking of instruments in terms of the impact on consumption is similar to that of the unskilled worker, with the exception of corporate income tax and labor tax. Resilience financing with corporate taxes reduces skilled household consumption because it reduces the formal sectors' wage with the reduction in investment, but with a substitution towards more consumption and a decline in net-of-tax investment return. Financing with labor tax increase is most detrimental to skilled households' consumption who are employed in the formal sectors. These workers outmigrate and send back remittances, but with a net loss of household income and consumption. Financing with a cut in government transfers also reduces skilled workers' household consumption, albeit by less than in the unskilled worker household because of the ability to migrate. 
Figure 2. Dominica: Fiscal Instruments
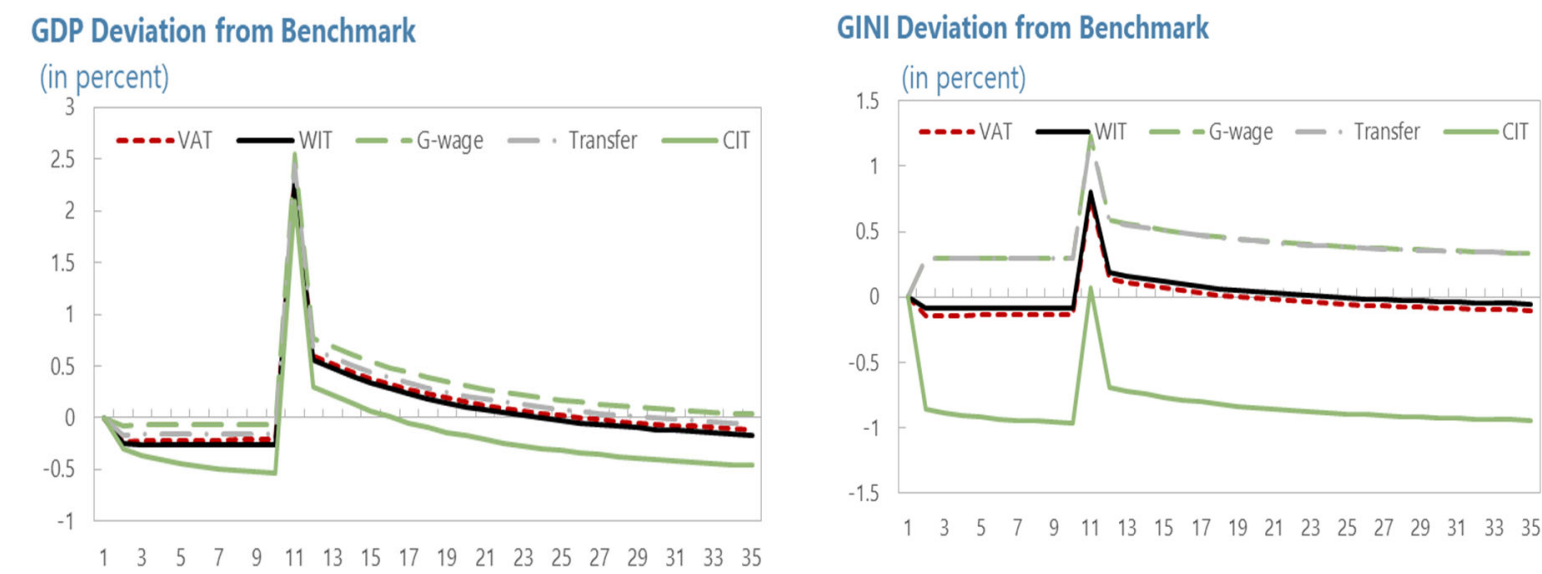

Unskilled worker consumption Deviation from Benchmark

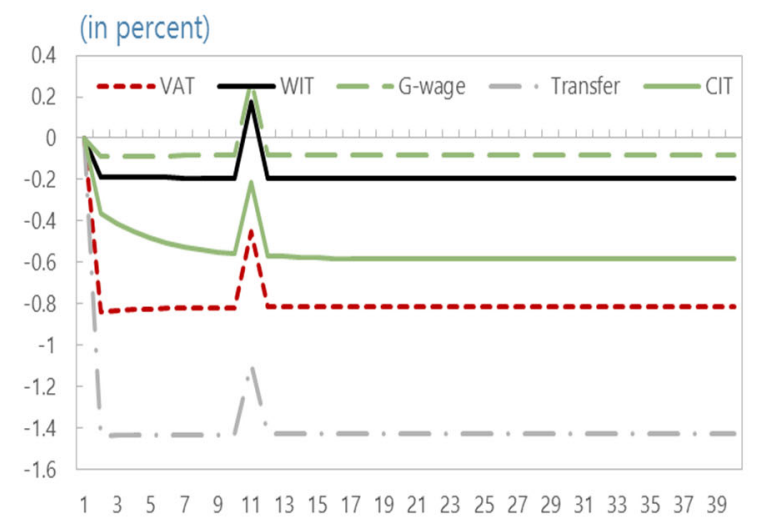

Skilled Worker Consumption Deviation from Benchmark (in percent)

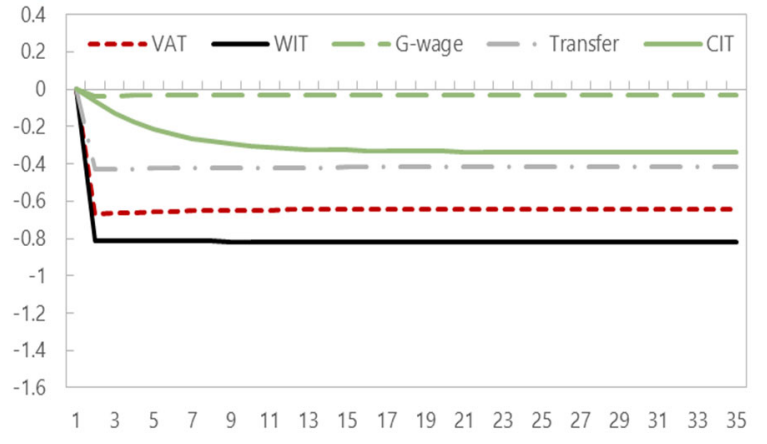

Note: each chart shows the series against the respective benchmark series. In each chart, the different fiscal instruments are considered to raise revenue to finance resilience building. The legend indicates: VAT (value-added tax), WIT (personal income tax), G-wage ( cut in government wage,) Transfer (cut in government transfers), and CIT (corporate income tax).

\section{The results highlight key policy tradeoffs between efficiency and inequality. Table 5} summarizes the policy instrument efficiency, as measured according to the impact of the policy financing instrument on output, and also on inequality, as measured by the GINI coefficient (with more equality ranking higher with a value of 1 ). The ranking is not surprising and matches standard priors about the general equilibrium impact of these instruments. However, a contribution of the model is the ability to combine all the specific SDS characteristics mentioned above and quantified output and inequality tradeoffs of alternative policy instruments. 


\begin{tabular}{|lcccc|}
\hline \multicolumn{5}{c}{ Table 5. Dominica: Policy Instruments Rankings } \\
& $\begin{array}{c}\text { VALUE-ADDED } \\
\text { POLICY }\end{array}$ & CORPORATE & GOVERNMENT & PUBLIC INVESTMENT \\
& 2 & TAXES & CONSUMPTION & \\
\hline OUTPUT & 3 & 3 & 1 & 4 \\
INEQUALITY (GINI) & 2 & 4 & 1 \\
\hline Source: Fund staff calculations. & & & & \\
\hline
\end{tabular}

\section{Conclusion}

24. Dominica is highly vulnerable to NDs that can have large human, economic, and social costs, making it critical to invest in resilient infrastructure. Given these costs, there are many benefits to build resilience for NDs, in terms of lowering the economic and social impact, speeding up recovery, and providing greater continuity in public services.

\section{This paper shows that the fiscal instrument used to finance investment in resilience is} critical to the efficiency and income distribution outcomes. The multi-sector general equilibrium model including key features of SDSs presented in this paper shows there are key policy tradeoffs in terms of efficiency and equity. Public investment in resilience has high returns in terms of output and employment, but it also increases inequality because the formal sector and skilled workers benefit the most from it in the long-term. However, resilient investment is shown to be critical in containing the income of poor households and informal workers in the aftermath of a ND, showing smaller increases in inequality after those events when more resilient investment is in place.

\section{Given that resilient investment is non-optional in SDSs highly exposed to NDs like} Dominica, addressing income inequality requires the use of other fiscal instruments. Corporate taxes and labor income taxes reduce income inequality but, as shown in this paper, they can have more negative impact in the long-run, especially in SDSs given the amplification effect on the loss of efficiency and output resulting from out-migration, limitted labor mobility across sectors due to skills' mismatches and labor informality, and limited of economic diversification. The use of transfers and value-added taxes are relatively more efficient, with a lower distortionary impact, but are less effective in terms of reducing income inequality. Given the difficult trade-offs in terms of economic efficiency and equity of tax instruments, inefficiencies in government spending appear as the most efficient way to finance costly resilient investment, including by reducing unproductive government employment to contain the wage bill, while increasing the efficiency of government transfers with better targeting can also provide fiscal space for investment in resilience while addressing income inequality.

\section{The efficiency-equity trade offs of government tax and and spensing instruments} underscores the importance of foreign grants to finance resilient investment. Grant financing contains income loss of low-income households after NDs while minimizing output and employment loss associated with tax distortions. Thereby addressing both efficiency and income distribution considerations, containing the increase inequality with the disproportionate impact of NDs on the workers with relatively lower wages. 


\section{References}

Acevedo, S. 2014. "Debt, Growth and Natural Disasters: A Caribbean Trilogy" IMF Working Paper $14 / 125$.

Barro, R. 2006a. "Rare Disasters and Asset Markets in the Twentieth Century." Quarterly Journal of Economics, 121: 823-899.

Barro, R. 2006b. On the Welfare Costs of Consumption Uncertainty, NBER Working Paper No. 12763.

Barro, R. 2009. "Rare Disasters, Asset Prices and Welfare Costs." American Economic Review, 99(1): 243-264.

Bevan, D. and C. Adam, 2016. "Financing the Reconstruction of Public Capital after a Natural Disaster." World Bank Policy Research Working Paper 7718.

Borensztein, E., Cavallo, E., and Jeanne, O., 2015. "The Welfare Effects from Macro-Insurance Against Natural Disasters." NBER working paper No. 21674.

Boustan L., Kahn M., Rhode P., and Yanguas M., 2017. "The Effect of Natural Disasters on Economic Activity in US Counties: A Century of Data." NBER Working Paper No.

Bussolo, M. and Medvedev, D., 2007. "Do remittances have a flip side? A general equilibrium analysis of remittances, labor supply responses, and policy options for Jamaica. World Bank working paper series 4143.

Cantelmo, A., Melina, G. and Papageorgiou, C., "Macroeconomic Outcomes in Disaster-Prone Countries. International Monetary Fund working paper series No. 19/217.

Cavallo, E. A., and Noy, I., 2011. "Natural Disasters and the Economy: A Survey." International Review of Environmental and Resource Economics, 5: 63102.

Cavallo, E., Galiani,S., Niy, I., and Pantano, J., 2013. "Catastrophic Natural Disasters and Economic Growth." Review of Economics and Statistics, 95(5): 1549-1561.

Dongyeol L., Huan Z., and Chau N., 2018. "The Economic Impact of Natural Disasters in Pacific Island Countries: Adaptation and Preparedness". IMF Working Paper 18/108.

Easterly, W. and Kraay, A., 2000. Small States, Small Problems? Income, Growth, and Volatility in Small States. World development, 28(11), pp.2013-2027. 
Felbermayr, G., and Gröschl, J., 2014. Naturally Negative: The Growth Effects of Natural Disasters. Journal of Development Economics, 111, 92-106.

Fomby, T., Ikeda, Y., and Loayza, N. V., 2013. The Growth aftermath of Natural Disasters. Journal of Applied Econometrics, 28(3), 412-434.

Hwang J.C., 2002/3. "Forms and rates of economic and physical depreciation by type of assets in Canadian Industries", Journal of Economic and Social Measurement, 28, 89-108.

Jorgenson D.W., 1996, 'Empirical studies of depreciation', Economic Inquiry, 34(1), 24-42.

Lee, D., and Zhang H., 2019. "Export Diversification in Low-Income Countries and Small States: Do Country Size and Income Level Matter?" International Monetary Fund Working Paper series No. $19 / 118$.

Lee D. , Zhang H. , and Nguyen, C., 2018, "The economic impact of natural disasters in Pacific Island countries: adaptation and preparedness.". International Monetary Fund, Working Paper series No. 18/108.

Marto, R., Papageorgiou, C., and Klyuev, V., 2017. Building Resilience to Natural Disasters: An Application to Small Developing States. IMF Working Paper, 17/223.

McIntyre, A., Li, M.X., Wang, K., and Yun H., 2018. Economic Benefits of Export Diversification in Small States. IMF Working Paper, 18/86, International Monetary Fund, Washington.

Noy, Ilan. 2009. "The Macroeconomic Consequences of Disasters." Journal of Development Economics, 88(2): 221-231.

Rasmussen, T. N. 2004. "Macroeconomic Implications of Natural Disasters in the Caribbean." IMF Working Paper 04/224.

IMF, 2016, Small States' Resilience to Natural Disasters and Climate Change - Role for the IMF, IMF Policy Paper.

UN, 2015, "World Population Prospects: The 2015 Revision", United Nations, New York.

Valentinyi, A., and B. Herrendorf, 2008, Measuring factor income shares at the sectoral level, Review of Economic Dynamics 11 (2008) 820-835. 


\section{MEASURING THE SHADOW ECONOMY IN DOMINICA ${ }^{1}$}

Knowing the size of the shadow economy, or all economic activities that would contribute to national GDP but are not officially recorded, can have a significant impact on the design and outcomes of public policies. We use the Multiple Indicators Multiple Causes (MIMIC) model to estimate the size of the shadow economy in Dominica relative to other ECCU and Caribbean countries. We find that the the burden of taxation seems to increase the size of the shadow economy, but a larger tourism sector and better government regulatory quality tend to decrease it. A large shadow economy manifests in both lower real GDP growth rates and lower formal employment rates.

\section{A. Background and Motivation}

1. Measuring the shadow economy is critical to design effective public policies. The shadow economy, also known as hidden economy, cash economy or informal economy, refers to all economic activities hidden from official authorities that, if recorded, would contribute to national GDP (IMF 2018)2. Measuring it is critical to (i) formulate and evaluate well targetted public policies; (ii) observe trends of economic activity and employment; and (iii) determine linkages between growth and employment. Several factors can lead to informality, including: monetary (to avoid paying taxes and/or social security contributions); regulatory (to evade bureaucracy or the burden of regulation); and institutional (corruption, quality of institutions and weak rule of law). Latin America, the Caribbean, and Sub-Saharan Africa have the highest informality in the world (IMF, 2018).

2. However, measuring the shadow economy is challenging. Direct approaches include enterprise and household surveys, government questionnaires, tax audits and other compliance methods. Because these data are often unavailable, inaccurate, or incomplete, indirect approaches are often favored. One such indirect estimation method is the MIMIC approach, which analyzes causes and indicators of informality through a dynamic general equilibrium model. Previous estimates of the MIMIC model (IMF 2008)3, found that a burdensome tax system, rigid labor markets, higher inflation, and the dominance of the agriculture sector are key determinants of informality, representing around 79 percent of the informal economy variance. This same study found that around $1 / 3$ of the Dominican economy is informal, one of the highest among the ECCU.

\section{B. Measuring the Shadow Economy in Dominica using the MIMIC Model}

\section{The MIMIC model measures the shadow economy through multiple indicators of}

economic outcomes. The MIMIC methodology relates a latent unobserved variable-the shadow economy - to its drivers (multiple causes) and observable variables (multiple indicators) that capture the size of the latent variablethrough a structural equation model. Hence, in the MIMIC model, the

\footnotetext{
${ }^{1}$ Results are obtained from a forthcoming working paper by Brozdowski, Khalid, Perez Marulanda, and Wang.

${ }^{2}$ Medina and Schneider (2018): Shadow Economies Around the World: What Did We Learn Over the Last 20 Years? IMF WP No. 18/17.

${ }^{3}$ Vuletin, G (2008): Measuring the Informal Economy in Latin America and the Caribbean. IMF WP No. 08/102.
} 
size of the shadow economy is not reflected in just one economic dimension, but it is simultaneously observed in multiple economic outcomes such as labor market and output market indicators. The MIMIC methodology offers greater flexibility over standard approaches that use single indicators to measure predict the size of unrecorded activities. ${ }^{4}$ The MIMIC methodology has been used frequently in countries with limited survey data onlabor markets data and informality, like countries in the ECCU.

\section{The rates of employment and real GDP growth are used as indicator variables, while} tax rates, the size of agriculture and tourism, and regulatory quality are used as causal variables. Our choice of indicator variables and causal variables are guided by existing literature, data limitations, and features specific to Caribbean economies. Hence, the size of the agricultural sector is frequently used as an indicator for the size of the informal economy, with undocumented activities increasing in the size of agriculture as a portion of the economy. We also consider the impact of the tourism sector, given its macrocriticality in the region. The burden of taxation is theoretically expected to increase the size of the shadow economy by increasing the cost of operating formally, with a larger tax wedge driving more agents into informal activity. On the other hand, the amount of enforcement activity undertaken by a government against evasion activities is likely to increase the cost of operating informally and therefore lower the size of the shadow economy. ${ }^{5}$ As indicator variables for the size of the shadow economy, we use the rate of real GDP growth and the rate of employment, both of which are hypothezised as having a negative relationship with the size of unreported economic activities in a country.

\section{Agriculture does not appear to contribute significantly to the size of the shadow} economy in our sample while size of the tourism sector is correlated with a smaller informal sector. Contrary to findings from the literature, while agriculture is positively related to the size of the shadow economy, this relationship is not statistically significant for our sample. ${ }^{6}$ On the other hand, a larger contribution of tourism to GDP is negatively related with the size of the shadow economy, suggesting that this sector is not contributing to informality in the region. Marginal corporate and personal income tax rates also show the expected positive relationship with the size of the shadow economy, and higher regulatory quality shows the expected negative relationship with the proportion of unreported economic activity. The relationship between the shadow economy and indicator variables is also consistent with theoretical predictions, with real GDP growth and employment rate being negatively related to the size of the shadow economy.

\footnotetext{
${ }^{4}$ Other indirect approaches, such as the currency demand approach and the electricity consumption approach, use single outcomes (currency in circulation and electricity use, respectively, to approximate unreported activities in the economy.

${ }^{5}$ We use the size of agricultural value added in the economy to proxy the contribution of agriculture, tourism as a percent of GDP, top marginal tax rates for corporate taxes and personal income taxes, and the Regulatory Quality Index from the World Governance Indicators of the World Bank.

${ }^{6}$ Our country sample consists of Antigua and Barbuda, Barbados, Costa Rica, Dominica, Dominican Republic, Grenada, Jamaica, Saint Kitts and Nevis, Saint Lucia, Saint Vincent and the Grenadines, Suriname, and Trinidad and Tobago.
} 
MIMIC Model Estimates for Size of Shadow Economy

(Structural Equation Model estimates)

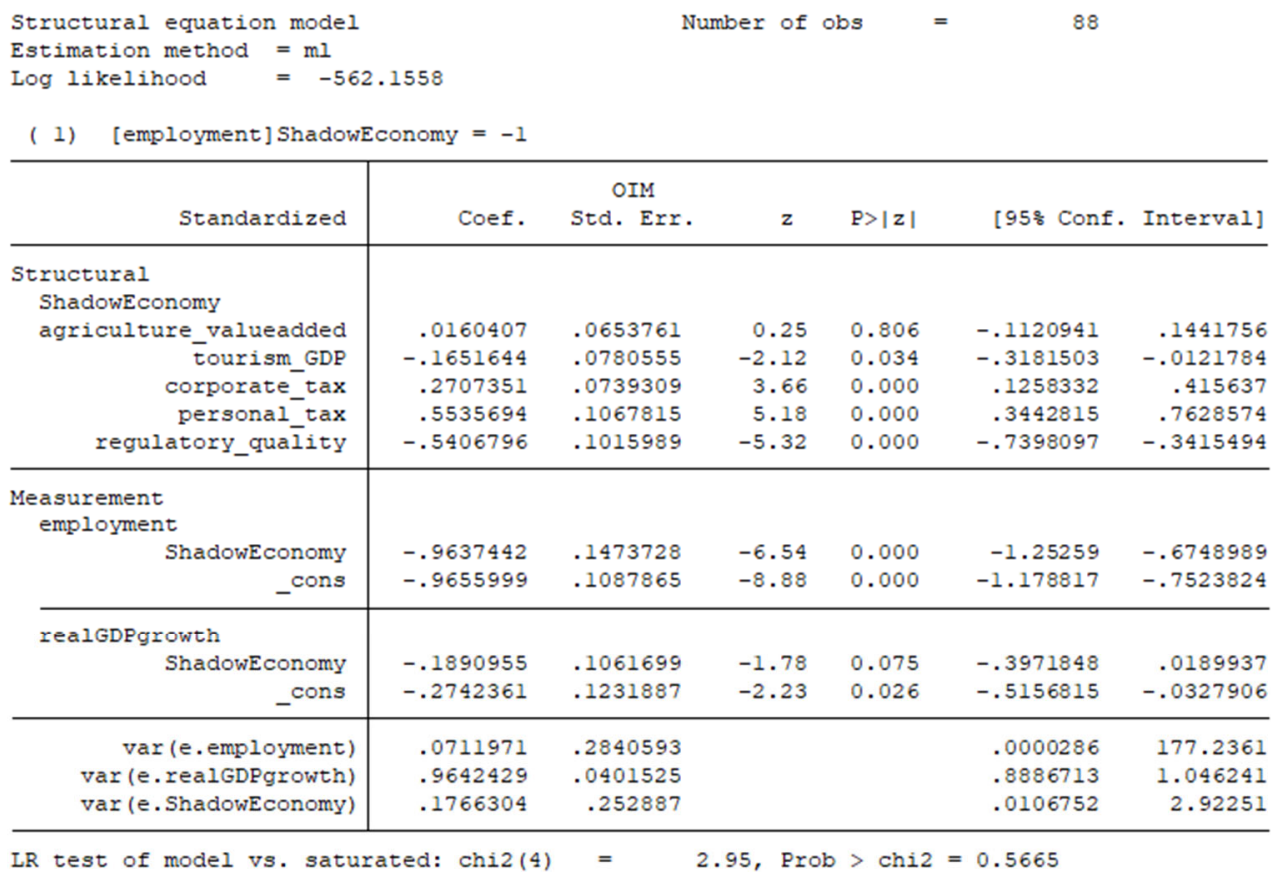

Sources: Fund staff estimates

\section{We estimate that the shadow} economy of Dominica averaged 46 percent of GDP over the 2011-19 period, on the high end of the ECCU countries. The absolute size of the shadow economy estimate is dependant on our chosen benchmark. ${ }^{7}$ However, even on a relative basis, Dominica lies on the high end of economies with sizeable shadow economies in the ECCU region.

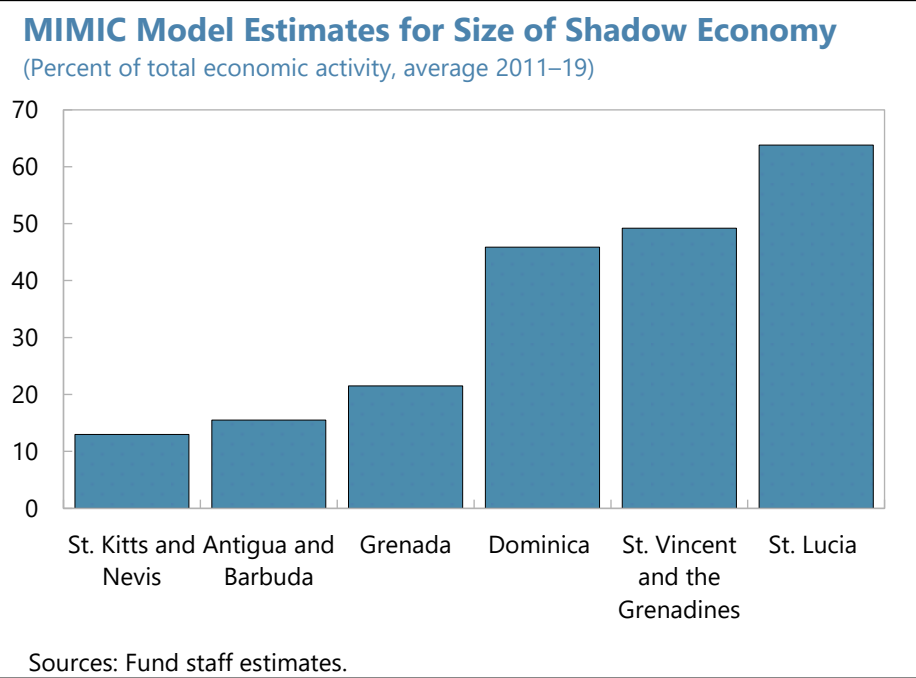

${ }^{7}$ See discussion on benchmarking in Schenieder and Buehn (2018). As our benchmark, we use the size of informal employment in Jamaica in 2015, measured by the Labor Force Survey. 


\section{References}

Medina, L. and Schneider, F. (2018): Shadow Economies Around the World: What Did We Learn Over the Last 20 Years? IMF WP No. 18/17

Vuletin, G. (2008): Measuring the Informal Economy in Latin America and the Caribbean. IMF WP No. $08 / 102$

Schneider, F., \& Buehn, A. (2018). Shadow economy: Estimation methods, problems, results and open questions. Open Economics, 1(1), 1-29. 